\title{
Pengaruh Environmental Cost Terhadap Kinerja Bisnis Dengan Kinerja Lingkungan Sebagai Variabel Moderasi
}

\author{
Ade Onny Siagian \\ Universitas Bina Sarana Informatika, ade.aoy@bsi.ac.
}

\begin{abstract}
The purpose of this study is about the effect of environmental cost on business performance with environmental performance as a moderating variable. The business performance variable in this study is the dependent variable, environmental performance as the moderating variable and environmental cost as the independent variable. This research uses illustrations of 13 (thirteen) manufacturing companies in the last 10 (ten) years from 2009 - 2018. The sample used in this research method is purposive sampling using statistics. The results of this research show that environmental costs have no effect on business performance, because the significant level is greater than 0.05 with a result of 0.976. Environmental performance in this research has an effect on business performance with a significant level of 0.005 . The moderating variable in this research affects business performance with a significant level of 0.025 .
\end{abstract}

Keywords: Business Performance, Environmental Cost, Environmental Performance

\begin{abstract}
ABSTRAK
Tujuan Penelitian ini merupakan tentang pengaruh environmental cost terhadap kinerja bisnis dengan kinerja lingkungn sebagai variabel moderasi. Variabel kinerja bisnis dalam penelitian ini sebagai variabel dependen, kinerja lingkugan sebagai variable moderating dan environmental cost selaku variabel independen. Riset ini memakai ilustrasi sebanyak 13 (tiga belas) perusahaan manufaktur dalam 10 (sepuluh) tahun terakhir terhitung dari 2009 - 2018. Sampel yang digunakan dalam Metode penelitian ini merupakan purposive sampling dengan memakai stata. Hasil dari riset ini menampilkan bahwa environmental cost tidak mempengaruh terhadap kinerja bisnis, sebab tingkatan signifikan lebih besar dari 0,05 dengan hasil 0,976. Kinerja lingkungan dalam riset ini berpengaruh terhadap kinerja bisnis dengan tingkat signifikan 0,005. Variabel moderasi dalam riset ini mempengaruhi terhadap kinerja bisnis dengan tingkat signifikan 0,025.

Kata Kunci : Kinerja Bisnis, Environmental Cost, Kinerja Lingkungan
\end{abstract}

Accepted: 02-11-2020, Revision: 16-01-2021, Published: 1-04-2021

\section{PENDAHULUAN}

Kinerja atau kemampuan bisnis merupakan kunci pokok untuk bertahan dalam era global sekarang ini. bagian industri, merupakan elemen utama dalam pembangunan ekonomi nasional. bukan hanya berpotensi mampu memberikan partisipasi ekonomi yang besar melalui nilai tambah, lapangan kerja dan devisa, namun mampu memberikan kontribusi yang besar sebagai penunjang pembentukan daya saing nasional. Kinerja bisnis industri merupakan suatu potret tentang kondisi keuangan suatu perusahaan yang dianalisis dengan instrument- instrumen analisis keuangan, sehingga dapat dikenali mengenai baik buruknya keadaan keuangan suatu perusahaan yang memantulkan prestasi kerja dalam periode tertentu. Hal ini sangat penting agar sumber daya digunakan secara optimal dalam menghadapi metamorphosis lingkungan.

Kemampuan bisnis yang baik dapat diperlihatkan dari laporan keuangannya, akan tergambar aktivitas perusahaan tersebut baik atau buruk. Dilihat dari pendapatan, laba usaha, dan laba bersih perusahaan yang terdaftar di BEI dan mengikuti atau memperhatikan dengan baik lingkungan sekitar atau disebut green company emiten srikehati. bahwa kinerja bisnis dari perusahaan yang memperhatikan lingkungannya berpenghasilan atau memiliki 
pendapatan yang meningkat dari tahun sebelumnya. Maka, Apakah terdapat pengaruh environmental cost, pengaruh kinerja terhadap kinerja bisnis, dan apakah terdapat pengaruh environmental cost terhadap kinerja bisnis dengan di moderasi kinerja lingkungan.

\section{KAJIAN LITERATUR \\ Grand Theory}

Teori legitimasi menyatakan bahwa terdapat kontrak sosial antara perusahaan dengan sistem social menurut (Harahap, 2013). Kontrak sosial tersebut mengikat perusahaan untuk bertindak sesuai dengan sistem sosial yang berlaku. Legitimasi dari masyarakat dapat menjadi faktor strategis bagi perusahaan untuk terus beroperasi dan berkembang di masa mendatang. Oleh karena itu, legitimasi merupakan faktor penting yang dapat menjadi alat bagi perusahaan untuk terus going concern menurut (Kristiana, 2012).

Menurut (Aisa, 2012), teori signal (Signalling Theory) mengartikan bahwa mengapa perusahaan mempunyai ajuran untuk memberikan informasi laporan keuangan kepada pihak eksternal. gerakan tersebut timbul karena adanya informasi asimetris antara perusahaan (manajemen) dengan pihak luar, dimana manajemen mengetahui informasi internal perusahaan yang relative lebih banyak dan lebih cepat dibandingkan pihak luar seperti investor dan kreditor. Kurangnya informasi yang diperoleh pihak luar tentang industri menyebabkan pihak luar membela diri dengan memberikan nilai rendah untuk perusahaan industri tersebut.

Menurut (Harahap, 2013), Teori stakeholder menyatakan sesungguhnya perusahaan bukan entitas yang beroperasi hanya untuk yang bersangkutan sendiri namun juga harus mampu memberikan manfaat bagi pelaksana kepentingannya. Teori stakeholders menjelaskan perusahaan tidak bisa lepas dari peran stakeholders aktivitas bisnisnya, sehingga perusahaan perlu memuaskan stakeholders, salah satunya dengan cara mengungkapan biaya lingkungan yang dilakukan perusahaan setiap tahunnya menurut (Buana, V. A., \& Nuzula, 2017). eksistensi suatu perusahaan sangat bergantung dari banyaknya dukungan yang diberikan oleh pelaksana kepentingan perusahaan tersebut.

Teori stakeholder menyatakan perusahaan tidak dapat terpisahkan dari lingkungan sosial sekitarnya. Oleh karena itu, perusahaan perlu menjaga hubungan dengan stakeholder dan mempertimbangkan apa yang diinginkan stakeholder dalam membuat kebijakan dan pengambilan keputusan sehingga perusahaan dapat mencapai tujuannya yaitu stability dan going concern menurut (Kristiana, 2012).

Namun penelitian terdahulu tersebut hanya menguji kinerja lingkungan yang menggunakan proper dan biaya lingkungan serta kinerja bisnis menggunakan data primer atau kuesioner. Serta hanya kinerja bisnis atau biaya lingkungan langsung terhadap kinerja bisnis, tidak dimoderasi. Oleh karena itu, riset ini berbeda dengan riset sebelumnya yaitu kinerja lingkungan sebagai variable moderating terhadap kinerja bisnis.

\section{Environmental Cost (Biaya Lingkungan)}

Biaya Kawasan atau lingkungan (environmental cost) adalah anggaran yang ditimbulkan akibat adanya kualitas lingkungan yang rendah, sebagai akibat dari proses produksi yang dilakukan perusahaan. Anggaran lingkungan wajib diberitahukan secara terpisah berdasarkan klasifikasi bebannya. Hal ini dilakukan supaya laporan biaya lingkungan dapat dijadikan informasi yang informatif untuk mengevaluasi kinerja operasional perusahaan terutama yang berpengaruh pada lingkungan.

Mengkategorikan anggaran atau biaya lingkungan menjadi empat kategori yaitu biaya pencegahan lingkungan, biaya penemuan, biaya kegagalan internal, dan biaya kegagalan eksternal, Selain biaya lingkungan, akuntansi lingkungan juga menjelaskan tentang keuntungan lingkungan.

Biaya lingkungan adalah keseluruhan biaya-biaya yang dipergunakan dalam mengukur ketidakpastian seperti limbah buangan. Anggaran lingkungan berhubungan dengan biaya proses, sistem, dan fasilitas penting dengan tujuan biar pengambilan keputusan manajemen bagus sekali menurut (Irawan, Dzulkirom AR, \& Zahroh ZA, 2016). biaya lingkungan merupakan akibat yang timbul dari aktifitas perusahaan yang 
berpengaruh terhadap mutu area lingkungan. Definisi anggaran lingkungan mencakup dari seluruh biaya-biaya yang paling nyata seperti limbah buangan.

Bagian akuntansi lingkungan ada elemen elemen pembiayaan yang harus dihitung, misalnya:

1. Anggaran operasionalisasi bisnis yang terdiri dari Anggaran depresiasi fasilitas lingkungan, anggaran memperbaiki fasilitas lingkungan, jasa atau pembayaran (fee) kontrak untuk menjalankan fasilitas pengelolaan lingkungan, anggaran tenaga kerja untuk menjalankan fasilitas pengelolaan lingkungan serta biaya kontrak untuk pengelolaan limbah (recycling).

2. Anggaran daur ulang yang dipasarkan.

3. Anggaran riset dan pengembangan (litbang) yang terdiri dari biaya total untuk material dan tenaga ahli, tenaga kerja lain untuk pengembangan material yang ramah lingkungan, produk dan fasilitas pabrik.

\section{Kinerja Lingkungan}

Kinerja lingkungan perusahaan menurut (Bahri \& Cahyani, 2016) adalah kinerja perusahaan dalam menemukan kawasan yang baik (green). Kinerja lingkungan adalah hasil dapat diukur dan dihitung dari sistem manajemen lingkungan, yang terkait dengan inspeksi aspek-aspek lingkungannya. Pengkajian kinerja lingkungan didasarkan pada kebijakan lingkungan, sasaran lingkungan dan target lingkungan. Environmental performance atau kinerja lingkungan merupakan kinerja perusahaan yang dilakukan kepada lingkungan dalam bentuk kepedulian dan akan memberikan manfaat di masa mendatang menurut (Aramico, Sudargo, \& Susilo, 2016). Kementerian lingkungan hidup indonesia menjelaskan bahwa kinerja lingkungan adalah hasil dari kebijakan pengelolaan sumber daya alam dan lingkungan hidup terintegrasi, guna membantu tercapainya pembangunan berkelanjutan, dengan mementingkan pada ekonomi hijau.

\section{Kinerja Bisnis}

Globalisasi merupakan sebuah isu strategis yang akan mempengaruhi perspektif bisnis ke depan. Kinerja atau kemampuan bisnis atau business performance adalah sebuah pendekatan secara top-down yang membantu pihak eksekutif memahami prosesproses yang dibutuhkan untuk mencapai tujuan strategis dan kemudian mengukur efektivitas dari proses-proses tersebut untuk memperoleh hasil yang diharapkan. Dapat dipahami bahwa kemampuan bisnis mengumpulkan proses-proses yang membantu perusahaan mengoptimalkan performa bisnisnya untuk menjamin tercapainya tujuan perusahaan.

Kemampuan bisnis adalah hasil dari kegiatan manajemen. Parameter yang sering digunakan untuk menilai kinerja suatu perusahaan yang dilakukan dengan menggunakan pendekatan di mana informasi keuangan diambil dari laporan keuangan atau laporan keuangan lainnya. Para pelaku bisnis perlu mengetahui tentang faktor-faktor yang mempengaruhi kinerja bisnis dan dimensi-dimensi dari faktor-faktor tersebut. Lebih penting dari semua itu tentunya para pelaku bisnis memerlukan dimensi yang dapat mengukur kirnerja bisnis baik yang bersifat kinerja financial (keuangan) atau kinerja non financial (non keuangan).

\section{Pengaruh Environmental Cost Terhadap Kinerja Bisnis}

Menurut (Irawan et al., 2016), persoalan lingkungan semakin banyak terjadi di seluruh dunia. Persoalan lingkungan tersebut yaitu kontaminasi lingkungan. Kegiatan industry menghasilkan limbah yang dapat mengontaminasi lingkungan. Perusahaan industri harus melakukan manajemen limbah sebelum dilepaskan di lingkungan sekitar. Biaya lingkungan berkaitan dengan biaya berlangsung, sistem, dan fasilitas penting dengan tujuan semoga pengambilan keputusan manajemen baik.

Menurut (Rafianto, 2015) hasil riset secara simultan memperagakan bahwa adanya dampak antara kinerja lingkungan dan pengungkapan Corporate Social Responsibility terhadap kinerja keuangan. Hasil riset secara parsial menunjukan bahwa kinerja lingkungan tidak berpengaruh signifikan terhadap kinerja keuangan, sedangkan pengungkapan Corporate Social Responsibility memiliki pengaruh yang 
signifikan terhadap kinerja keuangan. Biaya lingkungan berpengaruh negatif terhadap kinerja perusahaan menurut (Dewata, Jauhari, Sari, \& Jumarni, 2018). Hipotesis penelitian yang diajukan oleh peneliti berdasarkan penelitian terdahulu dan argumentasi yang disusun maka dapat dapat diusulkan hipotesis sebagai berikut:

H1: Environmental cost berpengaruh signifikan terhadap kinerja bisnis.

\section{Pengaruh Kinerja Lingkungan Terhadap Kinerja Bisnis}

Menurut (Bahri \& Cahyani, 2016), kinerja lingkungan adalah prosedur bagi industri untuk secara volunter mengintegrasikan kepedulian terhadap kawasan ke dalam operasinya dan hubungan dengan stakeholders. Semakin besar bagian perusahaan di dalam kegiatan lingkungan, maka semakin baik pula image perusahaan di mata stakeholders. Penting bagi industri untuk bertanggung jawab atas dampak yang ditimbulkan.

Menurut (Dewi \& Wirasedana, 2017), berdasarkan hasil analisis data dapat disimpulkan bahwa kinerja lingkungan tidak berpengaruh terhadap kinerja ekonomi. Hal ini berarti baik buruknya peringkat proper yang diraih oleh perusahaan yang merupakan proksi dari kinerja lingkungan bukan menjadi salah satu faktor yang mempengaruhi naik turunnya return saham yang merupakan proksi dari kinerja ekonomi. Hipotesis penelitian yang diajukan oleh peneliti berdasarkan penelitian terdahulu dan argumentasi yang disusun maka dapat dapat diusulkan hipotesis sebagai berikut:

$\mathrm{H} 2$ : Kinerja lingkungan berpengaruh signifikan terhadap kinerja bisnis.

\section{Pengaruh Environmental Cost Dengan Kinerja Lingkungan Terhadap Kinerja Bisnis}

Beberapa studi tentang kinerja bisnis telah dilakukan oleh para peneliti di seluruh penjuru dunia. Penelitian tersebut telah memberi masukan berharga bagi para pelaku bisnis khususnya dan perkembangan keilmuan manajemen strategic pada khususnya. Kinerja bisnis sangat penting untuk di jadikan bahan penelitian karena mencakup cukup luas bagi para pengusaha seluruh dunia. Penelitian terdahulu sudah cukup banyak untuk membahas kinerja bisnis tetapi faktor yang diambil berbeda-beda. Beberapa studi telah berhasil membuktikan hubungan antara variabel-variabel tertentu dengan kinerja bisnis.

membedakan kinerja dalam 2 (dua) bagian, pertama ukuran-ukuran kinerja berlandaskan pada biaya (costbased performance) seperti parameter profit dan ukuran-ukuran kinerja berdasarkan pada revenue (revenuebased performance) seperti penjualan dan pangsa pasar. Menurut (Lamore, 2010) menemukan Dampak yang positif dan signifikan dari inovasi terhadap kinerja bisnis. Dampak hubungan dari kedua variabel ini.

(Therin, 2003), menemukan bahwa pembelajaran organisasi berpengaruh secara langsung terhadap kinerja bisnis. Kinerja lingkungan berpengaruh positif pada kinerja perusahaan yang di proksikan dengan menggunakan Market Value Added (MVA). Kinerja lingkungan berpengaruh positif pada pengungkapan Corporate Social Responsibility. Pengungkapan Corporate Social Responsibility berpengaruh positif pada kinerja perusahaan yang diproksikan dengan menggunakan Market Value Added. Kinerja lingkungan berpengaruh positif pada kinerja perusahaan melalui pengungkapan Corporate Social Responsibility. Hipotesis penelitian yang diajukan oleh peneliti berdasarkan penelitian terdahulu dan komentar yang disusun maka dapat dapat diusulkan hipotesis sebagai berikut:

H3: Environmental cost berpengaruh signifikan terhadap kinerja bisnis dengan dimoderasi kinerja lingkungan.

\section{METODE PENELITIAN \\ Lokasi Penelitian}

Peneliti memilih perusahaan yang sudah tercatat dalam majalah swa 2018 top 25 green company, kinerja emiten Sri Kehati karena perusahaan sangatlah sesuai dengan judul peneliti. Perusahaan yang tercatat sangat memperhatikan lingkungan atas akibat yang dimunculkan oleh aktifitas operasi perusahaan. Serta melihat pentingya lingkungan perusahaan juga berpengaruh terhadap produktifitasnya dan lingkungan juga 
tidak luput dari akuntansi dalam arti lingkungan juga mengeluarkan biaya untuk diperhitungan oleh perusahaan dan harus dipertimbangkan serta diperhatikan. Populasi yang dipakai dalam riset ini adalah industri yang terdaftar di Bursa Efek Indonesia, sedangkan sampel riset ini diambil dengan teknik pusposive sampling dengan barometer pengambilan percontoh: a) perusahaan yang tercatat di bursa efek Indonesia.

b) perusahaan yang termasuk dalam green company atau mengikuti program penilaian peringkat kinerja perusahaan dalam manajemen lingkungan hidup yang terdapat pada majalah swa 2018 .

c) perusahaan menerbitkan laporan keuangan dalam satuan rupiah untuk durasi yang berakhir pada tanggal 31 desember pada tahun 2009 - 2018 dengan bermaksud untuk meningkatkan komparabilitas atau Daya banding yang baik. Kemudian batasan operasional variabel adalah aspek pemeriksaan yang memberikan informasi bagaimana menemukan dan menghitung variabel - variabel tersebut dengan merumuskan secara singkat dan jelas, serta tidak menimbulkan berbagai interpretasi.

\section{Predeterminated Variable}

Predeterminated variable adalah variabel dominasi yang nilainya telah diperoleh terlebih awal sebelum menghitung nilai variabel endogenous. Predeterminated variable yang ditetapkan dalam riset ini dihitung seperti pada uraian di bawah ini.

a. Pre-Disclosure Environment, diukur dari menurut Global Reporting Initiative (GRI), lalu di index.

b. Growth Opportunities, dihitung dengan perbandingan nilai pasar saham terhadap nilai buku modal saham sebagai proksi untuk peluang perkembangan masa depan. Untuk kondisi di indonesia, perbandingan ini menimbang perbedaan antara penilaian pasar atas nilai industri dan perkiraan nilai agregat dari transaksi akuntansi yang diamanatkan Standar Akuntansi Keuangan (SAK).

c. Environmental Exposure, diukur dengan tingkat total asset yang paling terbesar atau tertinggi dari contoh industri menurut tingkatan industry yang berpeluang besar menghasilkan polusi melalui proses produksi perusahaan, karena total asset yang besar berarti menghasilkan produksi yang tinggi maka sangat berpeluang menghasilkan polusi dan mencemari lingkungan.

\section{Teknik Pengumpulan Data}

Riset ini menggunakan data sekunder yaitu data yang diperoleh oleh peneliti secara tidak langsung dari objeknya, tetapi melalui sumber lain, baik lisan maupun tulisan. Data sekunder dikumpulkan dari website dan sumber lainnya, lalu dilanjutkan dengan pencatatan, perekapan, kemudian penghitungan. Dalam penelitian ini teknik pengumpulan data yang digunakan adalah metode purpose sampling. Data dikumpulkan dengan cara melihat dari Laporan Tahunan Atau keuangan industri yang terdaftar di Bursa Efek Indonesia (BEI) dan website langsung perusahaan, sesuai dengan penelitian untuk mengumpulkan dan mendapatkan data data yang diperlukan dalam Riset ini. Sampel yang dicapai bertujuan kepada industri yang terdaftar di bei dan mengikuti atau memperhatikan lingkungan sekitar (Green Company). Statistik deskriptif didasarkan pada data yang telah dikumpulkan lalu dianalisis. Analisis ini digunakan untuk memberikan deskripsi mengenai variabelvariabel penelitian (environmental cost, kinerja lingkungan, dan kinerja bisnis) yang dapat dilihat dari jumlah evidensi, maksimum, minimum, angka normal, kisaran, dan standar deviasi. Selain itu Uji Asumsi klasik yaitu Uji Normalitas, Uji Multikolinearitas, Uji Autokorelasi, Uji Heteroskedastisitas dan Pengujian Hipotesis.

\section{PEMBAHASAN}

Penelitian ini meneliti perusahaan yang termaksud green company tergabung pada majalah SWA 2018 dan terdaftar di Bursa Efek Indonesia (BEI) selama periode 2009 - 2018. Data yang terkait dengan kinerja bisnis, environmental cost dan kinerja lingkungan diperoleh dari laporan tahunan masing-masing perusahaan.

Data perusahaan Green Company Dalam Majalah SWA 2018 tersebut terdiri dari 25 (dua puluh lima) perusahaan, yaitu ada sektor manufaktur. Dari seluruh perusahaan ini tidak digunakan sebagai sampel yaitu perusahaan 
yang memiliki data kurang lengkap dan sek tor finance, sebab bukti yang dipakai dalam riset ini dalam 10 (sepuluh) tahun terakhir. Tahun terhitung mulai dari tahun 2009 sampai dengan 2018. Sedangkan tidak semua perusahaan menyediakan laporan tahunan dan laporan keuangannya dalam sepuluh tahun terakhir.

\section{Statistik Deskriptif}

Statistik deskriptif yang digunakan dalam Riset ini meliputi mean, minimum, maksimum serta standar deviasi. Data yang diolah dalam penelitian ini data yang sudah di Logaritma Natural (Ln) Atau (Log). Data obs pada penelitian ini menunjukkan 130 sampel yang digunakan. Pada variabel kinerja bisnis memiliki rata - rata sebesar 34799.78. Environmental cost atau biaya lingkungan yang ada di setiap perusahaan yang dihasilkan rata - ratanya 0.1841507 , nilai paling rendah 0.128357 dan paling tinggi 0.8943415 . Kinerja lingkungan dilakukan pengujian statistik deskriptif memperoleh nilai minimum sebesar 11817.25, sementara nilai maksimum yang diperoleh sebesar 144182.2. Kinerja lingkungan memiliki rata-rata bernilai positif sebesar 49323.22 dan standar deviasi 27649.49, hal tersebut menunjukkan bahwa normal industri manufaktur yang terdaftar di BEI tahun 2009 - 2018 telah mendapatkan nilai evaluasi dengan cukup baik.

\section{Uji Normalitas}

Uji normalitas bermaksud untuk mencoba apakah dalam model regresi, variabel pengganggu atau residual memiliki distribusi rata rata (Ghozali, 2013). Uji normalitas yang dipakai dalam riset ini adalah shapiro wilk test dengan menggunakan taraf signifikansi 5\% jika P-Value $<0,05$ maka bukti tidak terdistribusi secara normal.

Hasil uji normalitas seperti yang diketahui jika model memenuhi asumsi rata rata apabila nilai combined K-S lebih besar dari nilai signifikansi 0,05 . Pada penelitian ini combined K-S nilainya adalah 0.115 , yang berarti data pada penelitian ini memenuhi syarat kenormalan.

\section{Uji Multikolinearitas}

Percobaan ini dilakukan untuk mengetahui apakah hubungan diantara variabel bebas atau independen memiliki masalah multikolerasi atau tidak. Multikolinearitas dapat dilihat dari nilai VIF (Variance Inflating Factor). Jika VIF $>10$ atau tolerance (1/VIF) adalah 0.01 atau kurang, maka variable independen tersebut terindikasi multikolinearitas.

VIF dari setiap variabel adalah 1.00 yang berarti lebih kecil 10. Nilai tolerance dari setiap variabel adalah 0.999573 yang berarti lebih banyak dari 0.01. Berdasarkan penjelasan diatas dapat disimpulkan bahwa penelitian ini terbebas dari multikolinearitas.

\section{Uji Autokorelasi}

Pengujian ini bertujuan untuk mencoba apakah dalam model regresi linear ada korelasi antara kekalahan pengganggu pada periode $\mathrm{t}$ dan kesalahan pengganggu pada periode sebelumnya (t-1). Pengujian autokorelasi dinyatakan bebas apabila nilai Prob $>F$ lebih besar dari nilai signifikan.

Nilai Prob $>F$ adalah 0.0022 . Hal ini dapat diartikan bahwa nilai Prob>F lebih kecil daripada nilai signifikan dan mengindikasikan adanya autokorelasi pada varabel-variabel dalam penelitian ini. Masalah autokorelasi dapat diatasi dengan melakukan Prais Winsten Regression Atau General Least Square (gls).

\section{Uji Heteroskedastisitas}

Pengujian ini dilakukan untuk melihat apakah varians variabel dalam model regresi sama atau tidak. Heteroskedastisitas dapat dilihat dari nilai Prob $>$ Chi square. Apabila nilai $\quad$ Prob $>$ Chi square $<$ a $\quad(5 \%)$ dapat dinyatakan adanya indikasi heteroskedastisitas.

Nilai Prob>Chi Square adalah 0.9177 atau lebih besar dari 0.5. Maka, dapat disimpulkan penelitian ini bebas dari heteroskedastisitas dan memenuhi asumsi homoskedastisitas.

\section{Uji Korelasi}

Metode riset yang berusaha menghubung - hubungkan antara satu unsur atau elemen dengan unsur atau elemen yang lain untuk menciptakan bentuk dan wujud baru yang berbeda dengan sebelumnya menurut (Sugiyono, 2014). 
Korelasi antara variabel kinerja bisnis tidak memiliki tingkat keeretan hubungan dengan variabel environmental cost. Sementara pada variabel kinerja bisnis terhadap variabel yang lainnya yaitu kinerja lingkungan memiliki koefisien korelasi sebesar 0,007 signifikan positif pada alpha 5\%. Hal ini menunjukkan bahwa kinerja lingkungn yang baik dalam sebuah perusahaan akan menghasilkan kinerja bisnis yang baik pula. Hasil tersebut dapat terindikasi autokorelasi.

\section{Pengujian Hipotesis}

\section{Pengujian Pengaruh Environmental Cost Dan Kinerja Lingkungan Terhadap Kinerja Bisnis}

Pengujian pengaruh environmental cost dan kinerja lingkungan terhadap kinerja bisnis. Biaya lingkungan termaksud didalamnya biaya csr dan bina lingkungan, kemitraan, dan biaya yang dikeluarkan untuk mengatasi masalah yang dilakukan atau ditimbulkan perusahaan terhadap lingkungan perusahaan atau masyarakat contohnya seperti penanggulangan limbah dan penanaman pohon dilingkungan masyarakat. Serta laba bersih sebagai pengukuran dari environmental cost. Ukuran kinerja lingkungan dengan perhitungan kinerja bisnis, PD (PreDisclosure) diperhitungkan dengan GRI, GO (Growth Opportunities) diperhitungkan dengan nilai pasar saham, total ekuitas, jumlah saham yang beredar, nilai buku modal saham, Enx (Environmental Exposure) diperhitungkan dengan nilai tertinggi total asset perusahaan. Keduanya pengukuran ini membentuk dua hipotesis, yaitu (H1) Dan $(\mathrm{H} 2)$ yang diuji pengaruhnya dengan kinerja bisnis.

Langkah yang pertama dilakukan dalam penelitian ini adalah pemilihan model yaitu commond effect model, fixed effect model dan random effect model. Pengunjian dapat menggunakan Uji Chow, Uji LM dan Uji Hausman. Uji Chow membandingkan antara commond effect model dan fixed effect model, pada penelitian ini nilai rho yang dihasilkan $0.79008751>0,5$ maka fixed effect model lebih baik dari pada commond effect model. Uji ML membandingkan antara commond effect model dan random effect model, dari hasil pengujian ini nilai Prob > Chibar2 yang dihasilkan $0.0000<0,05$ maka lebih kecil dari tingkat signifikansi, maka random effect model lebih baik.

Sementara uji hausman yang dihasilkan $0.9420>0,05$ maka random effect model lebih baik dari pada commond effect model. Dari hasil pengujian ketiga model ini maka dapat ditarik kesimpulan bahwa model yang paling sesuai random effect model.

\section{Pengujian Pengaruh Environmental Cost Terhadap Kinerja Bisnis Yang Di Moderasi Oleh Kinerja Lingkungan}

Pengujian pengaruh environmental cost terhadap kinerja bisnis yang dimoderasi oleh kinerja lingkungan. Selanjutnya pada model ini melakukan perkalian dari setiap variabel environmental cost dan variabel kinerja Lingkungan agar adanya interaksi atau sebagai pemoderasi hubungan dengan kinerja bisnis.

Pada model ini juga langkah yang pertama dilakukan dalam penelitian ini adalah pemilihan model yaitu commond effect model, fixed effect model dan random effect model. Pengunjian dapat menggunakan Uji Chow, Uji LM dan Uji Hausman. Uji Chow membandingkan antara commond effect model dan fixed effect model, pada penelitian ini nilai rho yang dihasilkan $0.73909246>0,5$ maka fixed effect model lebih baik dari pada commond effect model. Uji ML membandingkan antara commond effect model dan random effect model, dari hasil pengujian ini nilai Prob > Chibar2 yang dihasilkan $0.0000<0,05$ maka lebih kecil dari tingkat signifikansi, maka random effect model lebih baik. Sementara uji hausman yang dihasilkan $0.7412>0,05$ maka random effect model lebih baik dari pada commond effect model. Dari hasil pengujian ketiga model ini maka dapat ditarik kesimpulan bahwa model yang paling sesuai random effect model.

Selanjutnya dilakukan uji asumsi klasik pada model kedua ini sama dengan model pertama hasil datanya memenuhi syarat kenormalan yaitu diatas signifikan 0.05. Selanjutnya masalah autokorelasi juga terdapat dalam percobaan model kedua ini dimana hasil uji autokorelasi dibawah nilai signifikan 5\%, maka mengindikasikan terjadinya autokorelasi. Solusinya untuk tidak terkena autokorelasi dilakukan percobaan dengan General Least Square (gls). 


\section{Pembahasan Hasil Penelitian}

Secara keseluruhan model estimasi pada model pertama dan kedua adalah signifikan dengan Prop F (Stat) Sebesar 0.000. Artinya bahwa model ini valid dan beberapa variabel independen mampu mempengaruhi variabel dependen.

\section{Pembahasan Hipotesis Pengaruh Environmental Cost Terhadap Kinerja Bisnis}

Pada tahapan ini terdapat hipotesis yang dibuktikan, yaitu hipotesis pertama. Hasil pembuktian yaitu tentang pengaruh environmental cost terhadap kinerja bisnis menunjukkan nilai koefisien 3883.866 dengan Prob T-Stat 0.976 tidak signifikan. Hal ini berarti bahwa hipotesis pertama ditolak. Hal ini menunjukkan bahwa environmental cost tidak dapat menjamin atau mendorong suatu perusahaan menjadi atau memiliki kinerja bisnis yang baik. Hasil penelitian ini sejalan dengan penelitian terdahulu menurut (Mauliddina, 2018) bahwa biaya lingkungan tidak berpengaruh terhadap kinerja bisnis perusahaan. Hasil penelitian ini bertolak belakang dengan penelitian yang dilakukan (Buana, V. A., \& Nuzula, 2017). yang menyatakan bahwa biaya lingkungan berpengaruh terhadap kinerja bisnis. Hal ini dapat dijelaskan oleh Fitriani, A. (2013), yang menyatakan bahwa tanggung jawab sosial perusahaan lewat berbagai dimensi biaya sosial kurang memiliki konsekuensi ekonomi (Economic Consequences) karena bentuk, tipe, dan strategi social cost yang dilakukan perusahaan lebih bersifat indirect effect, perusahaan melakukan tanggung jawab sosial lewat berbagai pengorbanan sosial (social cost) lebih dilihat dari perspektif dan motif manajemen, kurang memperhatikan dan memperhitungkan kebutuhan stakeholder, terutama stakeholder eksternal (masyarakat). Jadi dapat disimpulkan bahwa biaya lingkungan belum dapat menjadi bahan pertimbangan untuk meningkatkan kinerja suatu perusahaan, dikarenakan biaya lingkungan, sebagai salah satu indikator pengungkapan CSR, dinilai pihak stakeholder eksternal (masyarakat) tidak memiliki manfaat ekonomis langsung terhadap perusahaan ataupun produk yang dikeluarkan perusahaan tersebut sehingga belum dapat dijadikan pertimbangan masyarakat dalam membeli produk perusahaan tersebut.

Akan tetapi, riset ini konsisten dengan riset yang dilakukan oleh (Fitriani, 2013) yang menyatakan bahwa biaya lingkungan tidak berpengaruh terhadap kinerja keuangan.

\section{Pembahasan Hipotesis Pengaruh Kinerja Lingkungan Terhadap Kinerja Bisnis}

Hasil pembuktian hipotesis kedua tentang pengaruh kinerja lingkungan terhadap kinerja bisnis menunjukkan nilai koefisien 0.171761 dengan Prob T-Stat 0.005 signifikan. Hal ini berarti bahwa hipotesis kedua diterima. Hal ini menunjukkan bahwa kinerja lingkungan yang berkualitas atau baik dapat menjamin atau akan membuat juga kinerja bisnis yang baik disuatu perusahaan. Hasil penelitian ini konsisten dengan penelitian (Fitriani, 2013; Mauliddina, 2018; Permana \& Raharja, 2012; Siagian \& Prasetyo, 2020), yang juga menyatakan bahwa kinerja lingkungan berpengaruh terhadap kinerja bisnis. Hasil penelitian ini mendukung penelitian sebelumnya (Fitriani, 2013; Rafianto, 2015; Setiawan, Wahyu, Leonardo Budi H, 2016).

4.9.3. Pengaruh Environmental Cost Terhadap Kinerja Bisnis Yang Di Moderasi Oleh Kinerja Lingkungan

Hasil pembuktian hipotesis ketiga tentang pengaruh environmental cost yang dimoderasi oleh kinerja lingkungan terhadap kinerja bisnis. Hasil penelitian ini menunjukkan nilai koefisien positif sebesar 3.826387 dengan Prob T-Stat 0.025 signifikan pada alpha $1 \%$. Hal ini berarti bahwa hipotesis ketiga diterima. Membuktikan bahwa semakin tinggi environmental cost yang dimoderasi oleh kinerja lingkungan, maka semakin baik pula kinerja bisnis diperusahaan. Hal ini menunjukkan bahwa environmental cost yang dimoderasi kinerja lingkungan atau dalam arti lain biaya lingkungan yang dilakukan beriringan dengan kinerja lingkungan maka ada biaya yang dikeluarkan serta ada kinerja yang dilakukan akan membuat kinerja bisnis suatu perusahaan akan semakin baik pula bagi perusahaan itu sendiri dan masyarakat. Hasil penelitian ini sejalan dengan hasil penelitian (Basri, 2016). Penelitian ini juga didukung 
oleh hasil penelitian sebelumnya (Mustika, 2015). Menurut (Setiawan, Wahyu, Leonardo Budi H, 2016) bertolak belakang dengan riset sebelumnya yang menempatkan variabel sama dengan penulis yaitu biaya lingkungan dimoderasi kinerja lingkungan terhadap kinerja perusahaan, yang hasilnya tidak ada pengaruh antar variabel.

\section{SIMPULAN}

Pertama untuk pengujian untuk model pertama, memberikan bukti secara empiris bahwa environmental cost dan kinerja lingkungan sebagai proksi terhadap kinerja bisnis. bahwa environmental cost negatif tidak mempengaruhi kinerja bisnis. Hal ini menunjukkan bahwa environmental cost tidak dapat menjamin kinerja bisnis yang baik pada suatu perusahaan. Untuk pengujiaan kemampuan lingkungan memberikan bukti bahwa kinerja lingkungan mempengaruhi kinerja bisnis. Hasilnya bahwa kinerja lingkungan positif bermakna terhadap kinerja bisnis. Hal ini dibuktikan bahwa semakin tinggi atau baik kinerja lingkungan, maka semakin pula kinerja bisnis pada suatu perusahaan.

Kedua Untuk hasil pengujian environmental cost memberikan bukti bahwa kinerja lingkungan dinyatakan dapat memoderasi dalam hubungan antara environmental cost dengan kinerja bisnis. Membuktikan bahwa environmental cost yang dihasilkan dengan adanya kinerja lingkungan akan mempengaruhi terhadap kinerja bisnis suatu perusahaan. Hal ini membuktikan hasil yang signifikan bahwa environmental cost yang dimoderasi kinerja lingkungan atau biaya lingkungan yang dilakukan beriringan dengan kinerja lingkungan maka ada biaya yang dikeluarkan serta ada kinerja yang dilakukan akan membuat kinerja bisnis suatu perusahaan akan semakin baik pula bagi perusahaan itu sendiri dan masyarakat.

\section{REFERENSI}

Aisa, Lia dan Indarto. (2012). Analisis Manajemen Laba dan Kinerja Keuangan Sebelum dan Sesudah Merger dan Akuisisi pada Perusahaan Pengakuisisi yang Terdaftar di Bursa Efek Indonesia Tahun 2007-2009. Jurnal Fakultas

\section{Ekonomi. Universitas Semarang.}

Aramico, Basri, Sudargo, Toto, \& Susilo, Joko. (2016). Hubungan sosial ekonomi, pola asuh, pola makan dengan stunting pada siswa sekolah dasar di Kecamatan Lut Tawar, Kabupaten Aceh Tengah. Jurnal Gizi Dan Dietetik Indonesia (Indonesian Journal of Nutrition and Dietetics), 1(3), 121-130.

Bahri, Syaiful, \& Cahyani, Febby Anggista. (2016). Pengaruh Kinerja Lingkungan Terhadap Corporate Financial Performance Dengan Corporate Social Responsibility Disclosure Sebagai Variabel I Ntervening (Studi Empiris Pada Perusahaan Manufaktur Yang Terdaftar Di Bei). Jurnal Ekonika: Jurnal Ekonomi Universitas Kadiri, 1(2).

Basri, Z. (2016). Pengaruh Environmental Performance Dan Corporate Social Responsibility Disclosure Terhadap Kinerja Keuangan Perusahaan Pertambangan. Artikel Ilmiah.

Buana, V. A., \& Nuzula, N. F. (2017). Pengaruh Environmental Cost Terhadap Profitabilitas Dan Nilai Perusahaan (Studi Pada Perusahaan Kimia First Section yang Terdaftar di Japan Exchange Group Perode 2013-2015). Jurnal Administrasi Bisnis, 50(1), 4655.

Dewata, Evada, Jauhari, Hadi, Sari, Yuliana, \& Jumarni, Eka. (2018). Pengaruh Biaya Lingkungan, Kepemilikan Asing Dan Political Cost Terhadap Kinerja Perusahaan Pertambangan Di Indonesia. Jurnal AKSI (Akuntansi Dan Sistem Informasi), 3(2), 122-132.

Dewi, Ni Kadek Nyupina, \& Wirasedana, I. Wayan Pradnyantha. (2017). Pengaruh Kinerja Lingkungan Terhadapkinerja Ekonomi. E-Jurnal Akuntansi, 20(1), 526-554.

Fitriani, Anis. (2013). Pengaruh kinerja lingkungan dan biaya lingkungan terhadap kinerja keuangan pada BUMN. Jurnal Ilmu Manajemen (JIM), l(1).

Ghozali, Imam. (2013). Analisis Aplikasi 
Multivariate Dengan Program IBM SPSS 20. Semarang: Badan Penerbit Universitas Diponegoro.

Harahap, Sofyan Syafri. (2013). Analisis Kritis Atas Laporan Keuangan (Cetakan Ke). Jakarta: Penerbit Rajawali Pers.

Irawan, Aditya, Dzulkirom AR, Moch, \& Zahroh ZA, Zahroh Z. A. (2016). Efektivitas Biaya Lingkungan Dalam Upaya Meminimalkan Pencemaran Lingkungan (Studi Pada Pg Gempolkrep Mojokerto Periode 2013-2015). Jurnal Administrasi Bisnis, 40(1), 97-104.

Kristiana, Ira. (2012). Pengaruh Ukuran Perusahaan, Profitabilitas, Likuiditas, Pertumbuhanperusahaan Terhadap Opini Audit Going Concern Pada Perusahaan Manufaktur Yang Terdaftar Di Bursa Efek Indonesia (BEI). Berkala Ilmiah Mahasiswa Akuntansi, 1(1).

Lamore, P. R. (2010). Marketing - Research and development integration and market performance. In 31st Annual National Conference of the American Society for Engineering Management 2010, ASEM 2010.

Mauliddina, Septiani. (2018). Pengaruh environmental performance, iso 14001, Dan environmental cost terhadap kinerja Keuangan perusahaan manufaktur.

Mustika, R. R. (2015). Pengaruh Environmental Performance, Environmental Cost Dan Csr Disclosure Terhadap Financial Performance.

Permana, Virgiawan Aditya, \& Raharja, Raharja. (2012). Pengaruh Kinerja Lingkungan dan Karakteristik Perusahaan terhadap Corporate Social Responsibility (CSR) Disclosure (Studi Empiris pada Perusahaan Manufaktur yang Terdaftar di BEI). Diponegoro Journal of Accounting. Fakultas Ekonomika dan Bisnis. 1(2), 1-12.

Rafianto, R. A. (2015). Pengaruh Pengungkapan Corporate Social Responsibility dan Kinerja Lingkungan Terhadap Kinerja keuangan (Studi pada
Sektor Pertambangan di Bursa Efek Indonesia pada Periode 2010-2012). 2(1), 497-523.

Setiawan, Wahyu, Leonardo Budi H, A. P. (2016). Ukuran Perusahaan Terhadap Kinerja Keuangan Dengan Corporate Social Responsibility (Csr) Sebagai Variabel Intervening ( Studi Kasus Perusahaan Studi Kasus pada Perusahaan Manufaktur yang terdaftar di Bursa Efek Indonesia Tahun 20122016). 1-12.

Siagian, Ade Onny, \& Prasetyo, Trisna Fajar. (2020). Strategi Pengembangan Kompetisi Usaha Kecil Menengah Di Kabupaten Jombang. Jurnal Akrab Juara, 5(4), 77-85.

Sugiyono. (2014). Metode Penelitian Pendidikan Pendekatan Kuantitatif, Kualitatif dan $R \& D$. Bandung: Alfabeta.

Therin, François. (2003). Learning organization and innovation performance in high-tech small firms. 